\title{
Hindrances in port digitalization? Identifying problems in adoption and implementation
}

\author{
Olli-Pekka Brunila ${ }^{1,2^{*}} \mathbb{D}$, Vappu Kunnaala-Hyrkki ${ }^{1}$ and Tommi Inkinen ${ }^{2}$
}

\begin{abstract}
Digitalization has an impact on all domains of maritime transport and logistics. Ports' ability to act as a part of digital networks and information chains is vital for its competitiveness. This requires means and prerequisites to integrate with contemporary technology platforms and system architectures. Such readiness should exist in different parallel processes taking place in organizations of port communities. Successful digitalization requires focused technology management ensuring system and data transfer interoperability. The paper addresses problems, obstacles, and hindrances that ports are currently facing in their digitalization efforts. Interoperability and stakeholder interaction is significant, particularly between the port management, municipal ownership, and business operators and vendors. In the contemporary port development, environmental regulations have an effect on the level and effectiveness of digitalization. The future development of port digitalization will be dependent on the port capabilities to adopt and implement reliable and adoptable technologies with clear vision of the future.
\end{abstract}

Keywords: Port digitalization, Maritime logistics, Port management, Transport nodes

\section{Introduction}

\subsection{Background of port digitalization}

Digitalization is a megatrend that has changed maritime sector significantly (e.g. [21, 29, 37, 42]). Original reasons for port digitalization are in traditional efficiency optimization and in enhancement of material (cargo) flow (e.g. $[9,27]$. As ports evolved from load and offload points to genuinely intermodal logistical service hubs, the importance of efficient information flows increased (also [4]. At the core of it was the Electronic Data Interchange (EDI) [29]. Additionally, European Union was encouraging transportation towards paperless procedures regarding custom processes, freight documents and documents between cargo owner and contract carriers [17].

All international key-organizations are involved in the digital change. For example, International Maritime Organization (IMO) strongly supports the implementation of automated electronic data exchange between

\footnotetext{
*Correspondence: olli-pekka.brunila@xamk.fi

1 South-Eastern Finland University of Applied Sciences, Pääskysentie 1,

48220 Kotka, Finland

Full list of author information is available at the end of the article
}

ships and from ships to shore to increase efficiency, safety, and security of maritime navigation. Previous research has verified that digitalization offers significant potentials for ports to improve their efficiency, productivity, security, and sustainability (e.g. $[16,23,25,55,57$, 61]).

At the initial (starting) phases, it is vital that the ports carefully decide and compare, which technologies are to be integrated or newly installed into the daily operations. The transition towards a 'digital' or 'smart' port is difficult and complex process [13]. In the end, digitalization will evidently improve operational efficiency and productivity, increase safety, reduce emissions, and improve sustainability [18]. However, in the initial phases of digitalization, disadvantages of digitalization are likely to emerge. According to Inkinen et al. [31], the processes and operations in port communities are often quite conservative, when it comes to applying and collecting data driven operation solutions (in the case of shipping, see [3].

The level of digitalization varies between ports according to their size. Large ports often have more resources in 
their disposal, and they tend to be more active in development programs and collaborative research and innovation actions (e.g. European H2020 programs). Therefore, it is not surprising that they often have a higher level of digitalization than smaller ones. Specialization is a significant factor as small ports can be highly specialized (or they may serve only few customers) (e.g. [19, 47]).

Heilig et al. [29] have recognized three generations of digital transformation in ports, which are: (1) paperless procedures, (2) automated procedures, and (3) smart procedures. During 2010s and until today the contemporary transformation has been the most profound in system integration and in the adoption of IoT and artificial intelligence (AI) solutions that are often referenced as 'smart' procedures. Nevertheless, they concur with the notion that the level of digitalization between ports is varied. In practice, and sadly, in too many (port) cases, 'going digital' simple means small transitions on the first step, i.e. moving to paperless procedures. These are early steps in digitalization but too often particularly small ports satisfy to stay on the first early adoption level (paperless procedures).

Buck et al. [13] have developed a Digital Maturity Model (DMM) identifying four port maturity levels. They indicate the functional maturity of digitalization with the following categories:

1. Digitization of individual parties in the port;

2. Integrated systems in a port community: paperless data flows;

3. Logistics chain integrated with hinterland;

4. Connected ports in the global logistics chain resulting into digitalized port networks.

Both classifications $[13,29]$ may be further developed by using main technology domains, namely big data, automation and robotics, cyber-security, IoT and senser networks, cloud services, mobile platforms applications, and social media. These technology domains are essential tools in digitalization and they pose cause for conflicts and hindrances in adoption and implementation unless implemented with a long-term development plan or technology foresight process.

\subsection{Research questions, methodology and structure}

The aim of this paper is to identify and consider the potential problems and disadvantages related to port digitalization, especially at the initial phases, when ports are starting to adopt digital practices. This paper wants to highlight the importance of initial phase of digitalization, as it is crucial in the technology implementation: a wrong solution or decision made in this phase may lead to extensive extra costs and losses if the functionality and interoperability is not optimal. In the more advanced phases of digitalization, the basis for the digitizing work done in the ports is already set and thus, the challenges faced in these phases is often more easily solvable. The research questions are the following:

1. What are the most common challenges related to port digitalization in its initial phases?

2. Can these challenges become a disadvantage to the port?

3. How can the effects of these challenges be mitigated?

This paper relies on extensive literature review and the used references are interpreted through research and development project experience that our team has collected during the last decade in port digitalization (in detail "Appendix 1"). The literature review is based on selected references that have been collected from Web of Science (WoS) and Scopus databases. However, this is not a systematic literature review regarding the contents of the identified research papers, but a reflective review of the most important problems in port digitalization. For example, WoS search keywords 'port digitalization' produced 70 articles and correspondingly, Scopus search produced 103 articles. If additional search keywords 'problems' (only $10 \mathrm{WoS}$ articles and 16 Scopus articles) or 'hindrances' (both WoS and Scopus: zero articles) are used the amount of research is very limited, if not nonexistent. The list of references includes 61 items covering almost all suitable WoS references and also a majority of Scopus listed items (see references). The limited number of specifically devoted papers to this topic also motivates our paper, aiming to fill this observed research gap.

The structure of this paper is as follows: Chapter 1 provides the background, including the description of different maturity levels of digitalization in port context. Chapter 1 also establishes the research questions, methodology and structure of this paper. Chapter 2 presents the challenges posed by digitalization and how they can end up bringing disadvantages to ports. Chapter 3 provides examples on successful digitalization. Chapter 4 includes the discussion and conclusions of this paper.

\section{Challenges of digitalization in ports}

\subsection{Incompatible systems}

Ports are significant study areas as their large infrastructure and machinery investments are designed to last for several decades whereas IoT and other digital technologies have considerably shorter lifespans. This causes that IoT integration into the port infrastructure is required to be incremental and changeable. Interconnectivity is the main strength of IoT technologies as it provides adaptable solutions that may apply AI in order to gain optimal 
functionality (also [33]). Machine-to-machine interaction and self-operating automated processes are the keyelement in the pursuit for digitalization efficiency gains. Interoperability issues are considered to have an impact on the following development problems:

- How IoT raw data is collected and processed?

- What network types are used in the data transmissions?

- How and where the data is stored and how it will be restored?

- How the data analytics are performed?

- What are the impacts of the analytics?

- How the results are enriched with external data or external systems?

Digitalization allows smaller ports and logistics companies to connect themselves on digital platforms and be a first step of a globalized network. Being a part of a globalized network brings advantages and opportunities, but also puts pressure to initiate price competition between ports [50]. Yet, digitalization is not without its difficulties especially in the early adoption phases. Incompatible systems can present challenges as the various operators within the ports' logistical chain, such as other ports and shipping companies, digitalize their operations in different phases and at varying intervals. This is particularly problematic if the systems designs are for integration technology domains: inoperability causes severe challenges that are expensive to redesign and reinstall. This leads to additional costs (losses can be significant) and not to the desired efficiency gains.

As an example, IoT development is directly linked to sensor technologies and 5G networks (e.g. [1]). Technologically all equipment are interacting through IoTs and are equipped with their specific Internet Protocols (IPs). This makes them traceable and identifiable enabling remote governing of individual devices and applications. Problems in interoperability cause severe problems in implementation if procurements are not seamlessly executed. Gartner [22] anticipates that the number of devices connected to the IoT 'sphere' is going to increase almost exponentially until 2025 (estimation 25 billion devices worldwide).

IP device connectivity will be an essential driver of change in machine-to-machine communications in ports. IoT solutions also create a market for control applications (e.g. for smart phones). Integrative solutions collecting and distributing data is expected to be significant development area in the near future. According to Inkinen et al. [30] this is supported by generic technology trajectories: devices costs are decreasing and the physical device sizes are getting smaller. Device self-monitoring enables automated maintenance reporting and thus diminishes the role of human factor in operations management (also [20]). In the case of ports, the highest expectations are placed on autonomous vehicles in stevedoring. There is a societal potential conflict as these operations are still relatively labor intensive, and fully automated or remotely controlled up-downloading processes will probably cause opposition in labor unions (see [11]).

Ports and port related companies (including stakeholders) operate with different equipment and they often require different technology solutions. Ecosystems building has been one response to this enabling better interoperability between production manufacturers and the logistics service providing companies. Ecosystems are typically closed or third parties have access only to specific information on the need basis. This silo-based approach can even lead to incompatible data between different operators. Even the data transparency can become an issue when competing companies are obliged to share data in a business ecosystem [26]. Additionally, issues related to the ownership of the information and the applied rules and processes often lead to a situation, in which the same information is gathered multiple times by different parties. The gathered information is processed in separate information silos, thus duplicating the work. Lack of information sharing leads to operational bottlenecks and reduces efficiency (e.g. [14, 20, 44]).

Blockchain technology enables efficient use of decentralized and transparent database solutions (e.g. [56, 63]). The main benefit is highly reliably verification of documentation in different phases within a supply-chain. This increases traceability of transports and aids the automation processes e.g. in payments via smart phone applications. Societal benefits are evident as the high traceability makes misconduct ('grey economy') more difficult. In general, interoperability and trustworthiness are keydeciders whether or not blockchains will be extensively adopted into the operations. This has a direct impact on how ports will react and create their own data management systems.

On practical level, there are numerous examples from Europe. As such, DAKOSY (Datenkommunikationssystem AG) company is responsible for the Port Community System (PCS) implemented in the Port of Hamburg and has initiated the first blockchain project (in the summer 2018). PCS connects customs, authorities, forwards, importers and exporters, terminals and all transport modes together. The system includes over 2,500 integrated companies. It is paperless and single window type system [36]. During this project incompatibility problems were detected and were considered as one of the main hinderers in the technology implementation. 


\subsection{Digitalization requires resources and new perspective on management and warehousing}

Information warehousing and storing is often an unclear issue in ports (e.g. [30, 31]). Particularly in small ports, the whole information management can be handled/ operated only by one person and/or information resources are not coordinated and thus may be scattered in several databases. Information maintenance is not systematic and the formats of the information vary. The data is not always 'machine-readable', but it can be filed as PDF-files and map images. Port infrastructure information are often held by infrastructure companies (e.g. water companies), instead of the ports. Information systems provided by different operators do not generally work well together.

Internet trading and e-commerce are linked into the logistic chains, their development, and thus to ports. Perhaps the most visible part of application trading is in Mobility-as-a-Service (MaaS) that is often associated with consumer transport solutions. However, the main principle could be applied in all multimodal door-to-door logistic services and business-to-business (B2B) transactions. Again, the main challenges are not directly linked to digital technologies as such but rather to warehousing and movement of physical goods. This again requires flexibility and just-in-time principle agreements of contracts. There will be collaborative agreements between leading transport corporations (e.g. Maersk; CMA; CMG) and e-commerce houses (e.g. Amazon; Alibaba). The future formation of these markets will continue to be an important topic for academic research and the potentially changing role of third-party-logistics providers (3PLs) (for port-land interfacing, see [62].

Digitalized ports as logistical hotspots benefit from several positive associations: they improve transport chain transparency and provide more focused centralization for management that should have a positive impact on transportation times (efficiency). Emergence of blockchain technology improves transfer, reliability, and security of electronic agreements and documents. This again accelerates both financial and material flows and reduces the number of intermediaries in the chain and thus lowers the costs. For ports the consequent benefits manifest (most likely) as more efficient flow-through (e.g. pier time per tonnage) easing the pressure for capacity building. For example, even in the larger ports the cargo volumes must correlate with the size of the investment on the automation and robotics in order to be financially justifiable, even if the resources to conduct larger technology transformation projects would exist $[40,60]$.

A fundamental goal of digitalization is to improve cost-efficiency, meaning that it should bring about more efficient work flows and productivity and thus cause a decrease in costs. The metrics defining these are usually the saved time and resources. Planning is the key, as any technology investment should include a plan to ensure the human resources and skillsets match the intended use, so that the actual application and operation of these improvements and new technologies can actually be utilized to the required degree. In practice, new solutions are produced and implemented 'step-by-step' in daily operation. This means that there are simultaneous old and new processes applied at the same time. Data from the old system needs to be collected, transformed, and synchronized to the new system requiring knowledge and expertise on both systems [48].

Ports could be potential platforms and pilot areas for new solutions and development projects in digitalization. This is already in progress, as many ports are a part of new innovation and technology test-beds. However, the lack of continuity and implementation of project results is still a problem. Results are not often transferred to the production. The development of port related industrial innovations would require not only support or limited (e.g. start-up) funding, but also a responsible parties that would deploy and maintain the systems, bearing the initial risks, but holding a potential for future benefit in the case of successful commercialization [49].

\subsection{Smarting the port: digitalization, efficiency and competitiveness}

Ports are platforms (hubs) for activities that requires stakeholder collaboration (for an Asian case, see [52]). These stakeholders create networks and ecosystems for data sharing. This is a prerequisite for all system level development (e.g. [46]). In order to achieve maximum benefit from digitalization and data, the gathered data should be made available to all the relevant parties and it should be openly accessible. However, the benefits of shared data and compatible systems are not immediately apparent to port operators and thus there is a tendency that systems remain closed. Naturally, this limits data sharing and its' potential. As indicated earlier, open data sharing is one aspect of digitalization that faces resistance. Ports and logistics companies often do not share any information, unless it is obligatory, even though there would be identifiable benefits in doing so. Therefore, ports and the logistic sector require more information about digitalization and the solutions it provides $[8,12$, $15,35,54]$.

An important term used in the development reports produced for the practical needs of ports is'smart terminal'. The term 'smart' has been widely used in different contexts and the overall guiding principle in the use of the concept is that (digital) data and information sources are integrated into machine learning or other advanced 
automation processes. These digital entities (data algorithms) are capable for adjustable and flexible changes in the processes that they are a part of. These include for example the following:

- Creation of digital platforms for supply chain data exchange;

- Combination experiments of cargo flows among industrial organizations;

- Optimization experiments of cargo- and data flows in smaller ports;

- Development and holistic evaluation of a supply chain for a single industrial company.

In all of these experiments, port operators have a significant role as the goal is to identify best practices and implementing them (with scaling) to generic applicable models. Digitalization can even become a point of leverage and a competitive advantage, as the variation of different digital solutions and level of digitalization varies greatly between the ports. The risk for smaller ports to be lacking behind (with limited resources) in digital development is real. Considering the overall logistic chain, this can lead to a situation where only some segments of the chain are digitalized and smaller companies and ports are left out [40].

According to previous studies, smaller (port community) companies do not have similar recourses as larger ones when it comes to investing in digitalization (e.g. [48]). It is clear that cargo volumes in smaller ports are relatively small, which makes investments on digitalization unreasonable (in a short time span). An IT transformation project requires thorough planning and resourcing for a long term strategic goals. Initial scoping of the digitalization project should start with allocating the required resources for the planning, implementation and operation phases. For any digitalization or IoT project 'to go live' requires specialized skills from the users along with HR in charge of staffing.

Smaller ports in the Baltic Sea region are still in turn on developing their digital capabilities that would benefit their efficiency and productivity with cost-effectiveness. Correctly implemented, they are also key-tools in reducing environmental emissions and related costs (also on land transport, see [24]). To secure a smooth logistic chain, there is a distinct possibility that some shipping companies will choose their destination ports based on the port's capability of handling digitalized interactions and operations. Compatibility becomes essential whether or not the port systems are interoperable with the ones of shipping company. Finally, the impact of digitalization on competitiveness is also a maturity question. Particularly in the initiation phases the differences between economic gains are expectedly great between the early adopters and the late runners. However, these differences will decrease in time when technologies mature and become more affordable. This general technology phasing applies also in the context of ports.

\subsection{Security threats}

Digitalization of ports also gives rise to new security threats. For example, the amount, quality and sensitivity of the data transferred to a digital format carries with it threats as they pertain to information security and other cyber security related threats $[5,10,33]$. Cyber-security may be regarded as the most significant underlying factor hindering fast phase digitalization. Problematic includes cloud-service responsibilities, reliability of cloud-service provision, and intellectual property rights together with copyright agreements. Together these create an extensive growth potential for integrating legislation and technology domains.

Earlier research has identified cyber-security as the most important development field in port digitalization (e.g. [53]). This is understandable as it creates the (trust) foundation around all system developments. Port organizations (among the others) have started to develop their anticipatory guidance plans for cyber-attacks. Preliminaries for risk assessment require an inventory of existing devices, infrastructure, data and processes and clear definitions which of them are critical for port operations. Preparation plans for cyber-threats needs to updating regularly with predefined intervals and relatively short time-spans (max. 2 years). These plans commonly involve the following questions:

- What risks are possible to be targeted towards port systems?

- How to respond to these risks?

- How the risks are observed and identified?

- What to do after the detection?

- How to recover from the attack?

There are conventions and treaties such as SOLAS, ISM and ISPS focusing on safety and standardization of safety management of ships and ports issued by the regulative body IMO. However, it has provided only limited amount of guidance on cyber-security. The European Network and Information Security directive (NIS) is applied in European ports that are part of the TEN-T core network. However, this leaves a number of ports outside the reporting duty and the role of national cybersecurity center has become more significant in providing guidance and process governing [34].

Cyber-security has also attracted the attention of regulators and public sector. In 2018 an EU decree created a 
framework for Union's TEN-T core network data security for ports. Security issues will face a classical challenge of technological convergence or divergence. This entails also open-closed digitalization principles. Information classifications that are based on sensitivity require proper precautions and careful advance planning is the key to success. For example, data on cargo types and its movements require 'with care handling' and clear identity management (access rights to the data).

Data and systems, whether they be in closed, public or hybrid clouds, can bring about entirely new ways of organizing labor and work in ports increasing efficiency and productivity. They bring also a risk of external access if proper precautions to limit accesses are not up-to-date. Functions and operations within the infrastructure are particularly vulnerable to cyber-attacks. They are also more likely to be subject to criminal intentions. Particular attention should be focused on port operators as they are often less prepared for such hostile cyber-attacks than the ports themselves [6,28].

In practice, cyber-security threats in ports can include, for example, actions that do harmfully manipulate operational data. A precisely executed cyber-attack can gain access to commandeer a ship, access restricted data, take control of port operations or simply vandalize the system by changing cargo manifests or container numbers. Even 'small-scale' cyber-attacks can cause significant damage $[2,32]$. Identified vulnerabilities within ports are, among others: Insufficient preparedness for cyber-attacks, Lack of logs and monitoring for quick breach detection; Old versions of software with known security vulnerabilities; and Interdependence of networks.

\subsection{Resistance to digital change}

Digitalization may also face resistance from different actors and stakeholders. Resistances include negative attitudes towards digitalization, robotisation and automation. When it comes to automation and robotics, the resistance is often related to extremely high investment costs and the managerial fear of reduction in the need of human work force (e.g. [30]). Especially labor unions play a significant role on these issues. In brief, labor unions tend to view (in several cases) digitalization skeptically as they fear it would lead to a decrease in the need for workforce.

Resistance can also rise from ignorance. Realizing the benefits of technology generally requires an understanding of the possibilities it has to offer providing basic knowledge of the fundamentals of these particular technologies. Blockchain, IoT and big data are widely used technical terms. Sometimes the benefits for ports are not immediately apparent due to numerous ways of using and interpreting them (terms might mean different things to different people). There can be a misconception that digitalization merely means that all information can be accessed on a computer or over the internet in a document format. Thus, ports and port related operators often require consulting on these topics. Digitalization and Internet of Everything (IoE) in the port sector means that the ports are able to acquire, process and analyze massive volumes of data from different sources.

Legislation is the most effective incentive to introduce new digital solutions related to sustainability, safety, and security. Legislation effectively minimizes some of the resistance effects towards digitalization. Current scale on emission control and measurement could not have been achieved without digital solutions. This is a recent example where regulation have harnessed digitalization as a vehicle for change rather than a goal in itself. Both EU and national legislations regulate port operations, which sets various economic incentives or disincentives. Regulatory instruments include jurisdiction and law-based decrees, restrictions, and licenses [41].

While regulation itself is an effective and relatively easy way to speed up the digitalization process, the actual implementation can be costly and complex to execute. Regulation might also create resistance rather than promote innovation $[38,58]$. Digital innovations can also create competitive advantages, particularly in environmental management issues, since the environmental performance can be even more efficient than current regulations require. This requires again strategic view of the future development when significant investments are done in ports and in transport sector in general. Early adopters have an advantage over others in the field after enforcing the new legislation [39].

\section{Examples of successful implementation of digitalization in ports}

Ports have commonly numerous ongoing digitalization projects. Ports usually participate in the projects only if they perceive the potential benefits, such as cost savings, decreasing environmental impacts, energy savings, or public relations gains large enough (see [51]). Development projects e.g. between ports and universities are often related to experimental piloting of new technologies (5G, IoT, working machines, emission measurements technology or energy-saving technologies). Ports function as platforms and test-beds for these pilots $[43,59]$.

Successful projects may produce different (applicable) outcomes that were originally intended. As an example, a new energy-monitoring model enables real-time energy consumption monitoring in ports. At first, the model was theoretical, and the aim was to develop it into a tool that allows ports to look at their operations. It was a part of Low Carbon Port Operations project (see "Appendix 1"). 
A new smart energy environmental system was created that is applicable not only in ports but also in the businesses of port customers. Another example from the same project is energy auditing that focused on an oil heating system in the harbor house. They main technology concerned an electric defrosting system on the pier sides. This yielded a set of optimal use levels of improving energy efficiency. Simultaneously, the carbon footprint reduced due to the lower energy consumption. Economic benefits were easy to detect after the system implementation.

Another project example is 5G-Future Innovation Platform for Logistics that develops a 5G pilot test network in the Finland's largest universal port (HaminaKotka). Adaption to new technologies (such as 5G) to boost digitalization requires significant knowledge about the technology itself and a comprehensive insight on implementation practices. Benefits can be seen easily through technical measures such as data transaction speed (Gb/Mb per second) or low latency readouts. The actual benefits may also present themselves when the actual operation takes place as it has been seen in this $5 \mathrm{G}$ project. Systems compatibility is important because it may be completed modularly in order to prolong technology lifespan and integration with other systems.

Cost, timeline, and allocated resources are other keyfactors for success. It is worthy to point out that e.g. 5G technologies are very different from the older $4 \mathrm{G}$ technologies (and what they can offer). Currently 5G technology applications for port industries are, in almost all of the cases, still it their piloting phases [45]. In 5G port piloting, such as our project example here, each specific case has to be built separately and set detailed requirements for signal frequency, and upload/download speed requirements. Single IoT devise does not require 5G network speed, but real time High Definition (HD) video needs especially high upload speed for professional operation. Future demands for better video resolution are required particularly for remote control and handling. It is clear that IoT devices will become common in ports and transport industry in the near future [7, 43, 44, 45]. $5 \mathrm{G}$ project has shown that frequency slicing is important when next piloting steps are taking place in testing and implementation.

Our third and final example of a successful digitalization implementation concerns Effectiveness of Pilotage project. It was a commissioned research, during which new indicators were designed and created in order to monitor the effectiveness of pilotage. Based on the research, the Finnish pilotage company Finnpilot Pilotage Ltd adopted an electronic system, in which pilots report incidents and other anomalies that have occurred during the act of pilotage. The overall merit was in the creation of measures enabling more detailed assessment of the effectiveness of pilotage. Project results also improved the safety of maritime traffic in Finnish coastal areas.

\section{Discussion and conclusions}

Digitalization has influenced maritime and port sector significantly during the last 10 -years. Still, especially smaller ports or logistics operators are in a transition phase of digitalization. Current information systems are still valid for a long time. The pace of change in digitalization in ports is relatively slow, but that does not only depend on the ports themselves, but also on the needs and capabilities of the port's customers to deploy new information systems. In order to achieve digital transformation, all parties in the transport chain should be capable to implement new systems, including the smaller players. Ports can play an increasingly important role by producing data and they also can transform towards (transport) information hubs.

Digitalization is also a mean to cut down environmental stress in ports and in maritime logistics. Repka et al. [49] addressed the impact of international maritime climate and environmental regulation on the Finnish economy in relation to ports' attitudes towards the technology implementation. Thus, there are several different ways to assess a ports digital maturity. Generally, the indicators of the port digitalization are classification according to a triad including the three main categories: (a) digitalization of information, (b) exchange of digital information; and (c) automation of information exchange and operations.

This paper identified potential problems and disadvantages related to port digitalization. We wanted to stress out the importance of the initial phase. In the start of a large-scale digitalization effort (or project), a clear vision of where the technology and the industry are heading, is vital. A wrong solution or decision made in this phase may lead to extensive extra costs and losses if the functionality. Planning for any tools or technology architecture can only be effective if it is paired with a strategic vision of where the industry is going. This way all the tools and applications to be utilized will support that strategy and take into consideration possible future expansion or modification needs. Technology is not adapted for the sake of digitalization, but to support a viable business need.

Usually, a modular solution for digitalization enables a flexible approach to future digitalization projects, taking into consideration the development needs and cost effectiveness early on. The initial phase is a defining moment in that if digitalization is only approached as a one-time thing, with one or two tools to be utilized for one set of functions, it usually ends up being a limiting factor for 
future growth. By planning the future with a strategy in mind, technologies can be procured with specifications which allow for possible future expansion projects.

The challenges of digitalization in ports are (mainly) related to incompatible systems, lack of resources, security threats caused by digitalization, and resistance towards digitalization. Stakeholders operate with different service provider solutions and equipment. These require and apply different operating principles and functionalities in their specific business ecosystems. In addition, there are data interexchange issues and different operator systems are not necessarily compatible: lack of information sharing also leads to operational bottlenecks. The disadvantages due to these challenges affect smaller ports the most, since they can have limited resources. Planning is essential and efficient technology integration requires human resources competence.

A worthy consideration is that, especially in the initial phase, digitalization has a significant impact on port competition. Ports are in different positions to embrace the upcoming changes-a crucial factor is the port size and the corresponding ability to use and retrieve resources (investments and upgrades). This may lead to partial optimization and digital divides between ports that are specializing to specific customer segments. The effects of digitalization on competitiveness will likely diminish in the future, as digitalization solutions become more common and widely available with lower costs. Nevertheless, there will be always competition between ports. Despite the fact that there are pros and cons in digitalization, ports should focus on their core business, which is to produce a platform for their customers. If digitalization boosts their operations, decreases costs and benefits environment it is worth for investment. Investing only 'because other ports are doing so' is not the right way to proceed.

Problems related to resistance to digitalization and especially to cyber-security are the greatest hinderers of technology adoption. In addition, cargo movement and cargo content data can be sensitive and require specific attention. Most vulnerable are the operators inside the port areas as they operate in closed environments. They may be under the impression that they do not require as extensive defenses against cyber-attacks. Ports and companies inside the port areas form a 'closed community' with fewer threats than businesses locating outside. Inside the port area, there might be open wireless networks or other poorly secured IT systems that are relatively easy targets for cyber-attacks.

For the future research, corporate and environmental legislations are key-drivers of digital port development. They contribute directly to increasing environmental demands on maritime transport sector creating a research agenda. In terms of current levels of digitalization, questions of open access and open data are prominent. Therefore, organizational culture, open data systems, and increasing information transparency may be a significant challenge for research and practical implementation. The benefits of digitalization, especially in a longer term ( +10 years), are undeniable and it has become a vital tool in logistics and transport sectors. Digitalization of ports offers significant opportunities especially in improving their efficiency and productivity, security, and sustainability.

\section{Appendix 1: A list of selected projects (organizational leader and partner roles) of the research units and teams authoring this paper. Their results provide the reference point for the interpretations made in this paper.}

\begin{tabular}{|c|c|c|c|}
\hline $\begin{array}{l}\text { Name of the } \\
\text { project }\end{array}$ & Time & Main topic & Funder \\
\hline $\begin{array}{l}\text { 5G-Future Inno- } \\
\text { vation Platform } \\
\text { for Logistics }\end{array}$ & 2019-2022 & $\begin{array}{l}\text { Construction } \\
\text { of } 5 \mathrm{G} \text { pilot test } \\
\text { network }\end{array}$ & ERDF \\
\hline $\begin{array}{l}\text { Reinforcing } \\
\text { Eastern Finland- } \\
\text { Estonia Transport } \\
\text { Corridor (REFEC) }\end{array}$ & 2018-2021 & $\begin{array}{l}\text { The impact of } \\
\text { new ferry route to } \\
\text { ports in the Baltic } \\
\text { Sea }\end{array}$ & $\begin{array}{l}\text { Interreg Central } \\
\text { Baltic }\end{array}$ \\
\hline $\begin{array}{l}\text { Port investments } \\
2016-2025\end{array}$ & 2020-2021 & $\begin{array}{l}\text { Port develop- } \\
\text { ment through } \\
\text { direct and } \\
\text { indirect invest- } \\
\text { ments including } \\
\text { digitalization }\end{array}$ & Traficom \\
\hline $\begin{array}{l}\text { Maritime com- } \\
\text { petence of the } \\
\text { future (MEROS) }\end{array}$ & 2018-2020 & $\begin{array}{l}\text { Future needs of } \\
\text { maritime compe- } \\
\text { tence in Finland }\end{array}$ & $\begin{array}{l}\text { Prime ministers' } \\
\text { office (Finland) }\end{array}$ \\
\hline Digiport & $2018-2020$ & $\begin{array}{l}\text { Port digitalization } \\
\text { and application } \\
\text { development }\end{array}$ & ERDF \\
\hline $\begin{array}{l}\text { Low carbon port } \\
\text { operations }\end{array}$ & 2016-2017 & $\begin{array}{l}\text { Sustainable tech- } \\
\text { nologies and port } \\
\text { environmental } \\
\text { efficiency }\end{array}$ & ERDF \\
\hline $\begin{array}{l}\text { Black Carbon (BC) } \\
\text { in shipping and } \\
\text { businesses }\end{array}$ & 2015-2017 & $\begin{array}{l}\text { BC emissions and } \\
\text { business poten- } \\
\text { tial for environ- } \\
\text { mentally friendly } \\
\text { port operations }\end{array}$ & $\begin{array}{l}\text { TEKES (Business } \\
\text { Finland) }\end{array}$ \\
\hline $\begin{array}{l}\text { Ports Observatory } \\
\text { for Performance } \\
\text { Indicator Analysis } \\
\text { (PORTOPIA) }\end{array}$ & 2013-2017 & $\begin{array}{l}\text { Port performance } \\
\text { and innovative } \\
\text { openings for col- } \\
\text { laboration }\end{array}$ & FP7-transport \\
\hline $\begin{array}{l}\text { Effectiveness of } \\
\text { Pilotage }\end{array}$ & 2016-2017 & $\begin{array}{l}\text { Monitoring of the } \\
\text { effectiveness of } \\
\text { pilotage }\end{array}$ & $\begin{array}{l}\text { Finnpilot Pilotage } \\
\text { Ltd }\end{array}$ \\
\hline
\end{tabular}




\begin{tabular}{|c|c|c|c|}
\hline $\begin{array}{l}\text { Name of the } \\
\text { project }\end{array}$ & Time & Main topic & Funder \\
\hline $\begin{array}{l}\text { Sea faring } \\
\text { regulation and } \\
\text { Finnish economy } \\
\text { (MERSU) }\end{array}$ & 2016-2017 & $\begin{array}{l}\text { Regulatory } \\
\text { changes enabling } \\
\text { business poten- } \\
\text { tial including } \\
\text { digitalization and } \\
\text { system providers }\end{array}$ & $\begin{array}{l}\text { Ministry of Trans- } \\
\text { port and Commu- } \\
\text { nication }\end{array}$ \\
\hline $\begin{array}{l}\text { Effectiveness of } \\
\text { Pilotage }\end{array}$ & 2013-2015 & $\begin{array}{l}\text { Monitoring of the } \\
\text { effectiveness of } \\
\text { pilotage }\end{array}$ & $\begin{array}{l}\text { Finnpilot Pilotage } \\
\text { Ltd }\end{array}$ \\
\hline
\end{tabular}

\section{Acknowledgements}

Not applicable.

\section{Authors' contributions}

$\mathrm{O}-\mathrm{PB}$ is the corresponding author and VK-H and Professor TI are co-authors. All authors read and approved the final manuscript.

\section{Funding}

Not applicable.

\section{Availability of data and materials}

Not applicable.

\section{Declarations}

\section{Competing interests}

The authors declare that they have no competing interests.

\section{Author details}

'South-Eastern Finland University of Applied Sciences, Pääskysentie 1, 48220 Kotka, Finland. ${ }^{2}$ Department of Geography and Geology, University of Turku, 20014 Turku, Finland.

\section{Received: 18 June 2021 Accepted: 23 November 2021}

Published online: 11 December 2021

\section{References}

1. Ahokangas, P., Matinmikko-Blue, M., Yrjölä, S., \& Hämmäinen, H. (2021) Platform configurations for local and private $5 \mathrm{G}$ networks in complex industrial multi-stakeholder ecosystems. Telecommunications Policy, 45(5), 102128. https://doi.org/10.1016/j.telpol.2021.102128

2. Alcaide, J. I., \& Llave, R. C. (2020). Critical infrastructures cybersecurity and the maritime sector. Transport Research Procedia, 45, 547-554. https://doi. org/10.1016/j.trpro.2020.03.058

3. Alop, A. (2019). The main challenges and barriers to the successful "smart shipping." TransNav, 13(3), 521-528. https://doi.org/10.12716/1001.13.03. 05

4. Baccelli, O., \& Morino, P. (2020). The role of port authorities in the promotion of logistics integration between ports and the railway system: The Italian experience. Research in Transportation Business and Management, 35, 100451. https://doi.org/10.1016/j.rtbm.2020.100451

5. Baltic Port Organization (2017). Talking port competitiveness, digitalization and cyber security Baltic Ports Conference 2017 speaker interview with Indra Vonck. Retrieved May 17, 2021, from http://www.bpoports. com/talking-port-competitiveness,-digitalization-and-cyber-securitywith-dr-indra-vonck-(deloitte).html.

6. Barreto, L., Amaral, A., \& Pereira, T. (2017). Industry 4.0 implications in logistics: An overview. Procedia Manufacturing, 13, 1245-1252. https://doi.org/ 10.1016/j.promfg.2017.09.045

7. Bastug, S., Arabelen, G., Vural, C. A., \& Deveci, D. A. (2020). A value chain analysis of a seaport from the perspective of industry 4.0. International Journal of Shipping and Transport Logistics, 12(4), 367-397. https://doi.org/ 10.1504/IJSTL.2020.108405
8. Bechtsis, D., Tsolakis, N., Vlachos, D., \& Srai, J. S. (2018). Intelligent Autonomous Vehicles in digital supply chains: A framework for integrating innovations towards sustainable value network. Journal of Cleaner Production. 181,60-71. https://doi.org/10.1016/j.jclepro.2018.01.173

9. Bouklata, A. \& Bensfia, C. (2020). Digitalization of port passage procedures: Focus on the transit time of Goods. In 13th international colloquium of logistics and supply chain management, LOGISTIQUA 2020, article nr. 9353931. https://doi.org/10.1109/LOGISTIQUA49782.2020.9353931

10. Bour, G., Bernsmed, K., Borgaonkar, R. \& Meland, P.H. (2021). On the certificate revocation problem in the maritime sector. Lecture Notes in Computer Science, LNCS, (vol. 12556, pp. 142-157). https://doi.org/10. 1007/978-3-030-70852-8

11. Bottalico, A. (2021). The logistics labor market in the context of digitalization: Trends, issues and perspectives. Lecture Notes in Logistics. https://doi. org/10.1007/978-3-030-58430-6

12. Brunila, O.-P. (2013). The Environmental Status of the Port of HaminaKotka. Publications of the Centre for Maritime Studies at the University of Turku A69/2013.

13. Buck, W., Gardeitchik, J. \& van der Deijl, A. (2019). Move forward: step by step towards a digital port. White paper. Port of Rotterdam, British Port Association.

14. Carlan, V., Sys, C., \& Vanelslander, T. (2016). How port community systems can contribute to port competitiveness: Developing a cost-benefit framework. Research in Transportation Business \& Management., 19, 51-64. https://doi.org/10.1016/j.rtbm.2016.03.009

15. Conca, A., Di Febbararo, A., Giglio, D., \& Rebora, F. (2018). Automation in freight port call process: Real time data sharing to improve the stowage planning. Transportation Research Procedia., 30, 70-79. https://doi.org/10. 1016/j.trpro.2018.09.009

16. D’Amico, G., Szopik-Depczyńska, K., Dembińska, I., \& loppolo, G. (2021). Smart and sustainable logistics of Port cities: A framework for comprehending enabling factors, domains and goals. Sustainable Cities and Society, 69, 102801. https://doi.org/10.1016/j.scs.2021.102801

17. Decision No 70/2008/EC of the European Parliament and of the Counci of 15 January 2008 on a paperless environment for customs and trade. Available at URL: http://data.europa.eu/eli/dec/2008/70(1)/oj.

18. Del Giudice, M., Di Vaio, A., Hassan, R., \& Palladino, R. (2021). Digitalization and new technologies for sustainable business models at the ship-port interface: A bibliometric analysis. Maritime Policy and Management. https://doi.org/10.1080/03088839.2021.1903600

19. Di Vaio, A., \& Varriale, L. (2020). Digitalization in the sea-land supply chain: Experiences from Italy in rethinking the port operations within interorganizational relationships. Production Planning and Control, 31(2-3), 220-232. https://doi.org/10.1080/09537287.2019.1631464

20. Efimova, O.V., Baboshin, E.B., Igolnikov, B.V. \& Dmitrieva, E.I. (2020). Promising digital solutions for the efficient technological and managerial processes on transport. In Proceedings of the 2020 IEEE international conference "quality management, transport and information security, information technologies", IT and QM and IS 2020, article nr. 9322861 (pp. 92-95). https://doi.org/10.1109/ITQMIS51053.2020.9322861

21. Fruth, M., \& Teuteberg, F. (2017). Digitixation in maritime logistics-What is there and what is missing? Operations, information \& technology. Cogent Business \& Management, 4, 1411066. https://doi.org/10.1080/ 23311975.2017.1411066

22. Gartner. (2019). Gartner Identifies Top 10 Strategic loT Technologies and Trends. https://www.gartner.com/en/newsroom/press-releases/201811-07-gartner-identifies-top-10-strategic-iottechnologies-and-trends. Accessed 25 Dec 2021.

23. Gebler, M., SchootUiterkamp, A. J. M., \& Visser, C. (2014). A global sustainability perspective on 3D printing technologies. Energy Policy, 74, 158-167. https://doi.org/10.1016/j.enpol.2014.08.033

24. Giuliano, G., \& O'Brien, T. (2007). Reducing port-related truck emissions: The terminal gate appointment system at the Ports of Los Angeles and Long Beach. Transport Research Part D: Transport and Environment, 12(7), 460-473. https://doi.org/10.1016/j.trd.2007.06.004

25. Gonzalez, O. A., Koivisto, H., Mustonen, J. M., \& Keinänen-Toivola, M. M. (2021). Digitalization in just-in-time approach as a sustainable solution for maritime logistics in the Baltic Sea region. Sustainability, 13(3), 1173. https://doi.org/10.3390/su13031173 
26. Gunes, B., Kayisglu, G., \& Bolat, P. (2021). Cyber security risk assessment for seaports: A case study of a container port. Computers \& Security. https://doi. org/10.1016/j.cose.2021.102196

27. Guo, W., Atasoy, B., van Blokland, W. B., \& Negenborn, R. R. (2020). A dynamic shipment matching problem in hinterland synchromodal transportation. Decision Support Systems, 134, 113289. https://doi.org/10.1016/j.dss.2020. 113289

28. Gupta, N., Tiwari, A., Bukkapatnam, S. T. S., \& Karri, R. (2020). Additive manufacturing cyber-physical system: Supply chain cybersecurity and risks. Special Section on Additive Manufacturing Security. https://doi.org/10.1109/ACCESS. 2020.2978815

29. Heilig, L., Lalla-Ruiz, E., \&Voß, S. (2017). Digital transformation in maritime ports: analysis and a game theoretic framework. NETNOMICS: EConomic Research and Electronic Networking, 18(2-3), 227-254. https://doi.org/10.1007/ s11066-017-9122-x

30. Inkinen, T., Helminen, R., \& Saarikoski, J. (2021). Technological trajectories and scenarios in seaport digitalization. Research in Transportation Business and Management. https://doi.org/10.1016/j.rtbm.2021.100633

31. Inkinen, T., Helminen, R., \& Saarikoski, J. (2019). Port digitalization with open data: Challenges, opportunities, integrations. Journal of Open Innovation, 5(2), 30. https://doi.org/10.3390/joitmc5020030

32. Jensen, L. (2015). Challenges in maritime cyber-resilience. Technology Innovation Management Review, 5(4), 35-39. https://doi.org/10.22215/TIMREVIEW/ 889

33. Jovic, M., Tijan, E., Aksentijevic, S. \& Cišic, D. (2019). An overview of security challenges of seaport loT systems. In 42nd international convention on information and communication technology, electronics and microelectronics, MIPRO 2019Proceedings, article nr. 8757196 (pp. 1037-1042). https://doi.org/10.23919/ MIPRO.2019.8757206

34. Jović, M., Tijan, E., Aksentijević, S., Sotošek, B. (2020). The role of electronic transportation management systems in seaport digitalization. In 32nd Bled eConference humanizing technology for a sustainable society, BLED 2019-Conference proceedings (pp. 1-15). https://doi.org/10.18690/978-961-286-280-0.1

35. Kane, G.C., Palmer, D., Phillips, A.N., Kiron, D. \& Buckley, N. (2015). Strategy, not technology, drives digital transformation. MIT Sloan Management Review. Deloitte University Press. Available at URL: https://www2.deloitte.com/conte nt/dam/Deloitte/fr/Documents/strategy/dup_strategy-not-technologydrives-digital-transformation.pdf.

36. Kapkaeva, N., Gurzhiy, A., Maydanova, S., \& Levina, A. (2021). Digital Platform for Maritime Port Ecosystem: Port of Hamburg Case. TransSiberia 2020 conference. Transportation Research Procedia, 54, 909-917. https://doi.org/10.1016/j. trpro.2021.02.146

37. Kayikci, Y. (2018). Sustainability impact of digitalization in logistics. Procedia Manufacturing, 21, 782-789. https://doi.org/10.1016/j.promfg.2018.02.184

38. Klemmensen, B., Pedersen, S., Dirkinck-Holmfeld, K., Marklund, A., \& Rydén, L. (2007). Environmental policy — Legal and economic instruments. The Baltic University Press.

39. Kunnaala V., Rasi M. \& Storgård J. (2013) Corporate social responsibility and shipping. Views of Baltic Sea shipping companies on the benefits of responsibility. Publications of the Centre for Maritime Studies at the University of Turku, A70/2013.

40. Kunnaala-Hyrkki, V., Brunila, O.-P., Nygren, P. \& Hämäläinen, E. (2015). Management of Ports' environmental effects-A comparative review. Publications of the Centre for Maritime Studies at the University of Turku A72/2015.

41. Kuronen, J., \& Tapaninen, U. (2010). Evaluation of maritime safety instruments. WMU Journal of Maritime Affairs, 9(1), 45-61. https://doi.org/10.1007/BF031 95165

42. Leviäkangas, P. (2016). Digitalization of Finland's transport sector. Technology in Society, 47, 1-15. https://doi.org/10.1016/j.techsoc.2016.07.001

43. Liu, Y., Tong, K., Mao, F., \&Yang, J. (2020). Research on digital production technology for traditional manufacturing enterprises based on industrial Internet of Things in $5 \mathrm{G}$ era. The International Journal of Advanced Manufacturing Technology, 107, 1101-1114. https://doi.org/10.1007/s00170-019-04284-y

44. Mattei, F. E. E. (2020). Port of the future: Addressing efficiency and sustainability at the Port of Livorno with 5G. Research report, 16. Retrieved May 15, 2021, from www.jstor.org/stable/resrep28304.

45. Minoli, D., \& Occhiogrosso, B. (2019). Practical Aspects for the Integration of $5 G$ networks and loT Applications in Smart Cities Environment. Wireless Communications and Mobile Computing, 2019, 5710834. https://doi.org/10.1155/2019/ 5710834
46. Pernia, O. \& de los Santos, F. (2016). Digital Ports - The evolving role of port authorities. Port Technology Journal Edition 69 (February). Retrieved March 20, 2021, from Available at URL: https://www.porttechnology.org/wp-content/ uploads/2019/05/Navis-PT169-8.pdf.

47. Philipp, R., Gerlitz, L., \& Moldabekova, A. (2020). Small and medium-sized seaports on the digital track: Tracing digitalisation across the South Baltic Region by innovative auditing procedures. Lecture Notes in Networks and Systems, 117, 351-362. https://doi.org/10.1007/978-3-030-44610-9

48. Qin, J., Liu, Y., \& Grosvenor, R. (2016). A categorical framework of manufacturing for industry 4.0 and beyond. Procedia CIRP, 52, 173-178. https://doi.org/10. 1016/j.procir.2016.08.005

49. Repka, S., Ojala, L., Jalkanen, J.-P., Alhosalo, M., Niemi, J., Pöntynen, R., Solakivi, T., Pohjola, T., Haavisto, R., Lensu, M., Erkkilä-Välimäki, A., Haukioja, T. \& Kiiski, T. (2017). The impact of international maritime climate and environmental regulation on the Finnish economy. Publications of the Government's Analysis, Assessment and Research Activities 55/2 017

50. Rozman, N., Vrabic, R., Corn, M., Pozrl, T., \& Diaci, J. (2019). Distributed logistics platform based on Blockchain and loT. Procedia CIRP, 81, 826-831. https://doi. org/10.1016/j.procir.2019.03.207

51. Sadiq, M., Ali, S. W., Terriche, Y., Mutarraf, M. U., Hassan, M. A., Hamid, K., Ali, Z., Sze, J.Y., Su, C.-L., \& Guerrero, J. M. (2021). Future greener seaports: A review of new infrastructure, challenges, and energy efficiency measures. IEEE Access, 9, 75568-75587. https://doi.org/10.1109/ACCESS.2021.3081430

52. Senarak, C. (2020). Shipping-collaboration model for the new generation of container port in innovation district: A case of eastern economic corridor. Asian Journal of Shipping and Logistics, 36(2), 65-77. https://doi.org/10.1016/j. ajsl.2019.11.002

53. Senarak, C. (2021). Port cybersecurity and threat: A structural model for prevention and policy development. Asian Journal of Shipping and Logistics, 37(1), 20-36. https://doi.org/10.1016/j.ajsl.2020.05.001

54. Srai, J. S., \& Lorenz, H. (2018). Developing design principles for the digitalization of purchasing and supply management. Journal of Purchasing and Supply Management., 25(1), 78-98. https://doi.org/10.1016/j.pursup.2018.07.001

55. Svaetichin, I., \& Inkinen, T. (2017). Port waste management in the Baltic Sea area: A four port study on the legal requirements, processes and collaboration. Sustainability, 9(5), 699. https://doi.org/10.3390/su9050699

56. Tsiulin, S., Reinau, K.H. \& Goryaev, N. (2020). Conceptual comparison of port commmunity system and blockchain scenario for maritime document handling. In Proceedings - 2020 global smart industry conference, GloSIC 2020, article nr. 9267847, (pp. 66-71). https://doi.org/10.1109/GloSIC50886.2020.9267847

57. Vairetti, C., González-Ramírez, R. G., Maldonado, S., Álvarez, C., \&Voß, S. (2019). Facilitating conditions for successful adoption of inter-organizational information systems in seaports. Transportation Research Part A: Policy and Practice, 130, 333-350. https://doi.org/10.1016/j.tra.2019.09.017

58. Vieira, J., Moura, F., \& Viegas, J. M. (2007). Transport policy and environmental impacts: The importance of multi-instrumentality in policy integration. Transport Policy, 14, 421-432.

59. Wang, Y., \& Sarkis, J. (2021). Emerging digitalization technologies in freight transport and logistics: Current trends and future directions. Transport Research Part E: Logistics and Transportation Review. https://doi.org/10.1016/j.tre.2021. 102291

60. Witkowski, K. (2017). Internet of things, big data, industry 4.0-Innovative solutions in logistics and supply chains management. Procedia Engineering, 182, 763-769. https://doi.org/10.1016/j.proeng.2017.03.197

61. Xiao, Y., Chen, Z., \& McNeil, L. (2021). Digital empowerment for shipping development: A framework for establishing a smart shipping index system. Maritime Policy and Management. https://doi.org/10.1080/03088839.2021. 1894364

62. Zeng, F., Chan, H. K., \& Pawar, K. (2021). The effects of inter- and intraorganizational factors on the adoption of electronic booking systems in the maritime supply chain. International Journal of Production Economics, 236, 108119. https://doi.org/10.1016/j.ijpe.2021.108119

63. Zikria, Y. B., Kim, S. W., Hahm, O., Afzal, M. K., \& Aalsalem, M. (2019). Internet of things (loT) operating systems management: Opprtunities, challenges, and solutions. Sensors, 19(8), 1793. https://doi.org/10.3390/s19081793

\section{Publisher's Note}

Springer Nature remains neutral with regard to jurisdictional claims in published maps and institutional affiliations. 